\title{
The Effect of Gembili Starch (Dioscorea esculenta) and Eubacterium rectal Supplementation on Skeletal Muscle Peroxisome Proliferator-Activated Receptor $y$ Coactivator $1 \alpha$ (Pgc-1a) Expression in Diabetic Mice Models
}

\author{
Tri Setyawati $^{1 *}$ (D), Rio Jati Kusuma ${ }^{2}$, Harry Freitag Luglio ${ }^{2}$, Neni Oktiyani $^{3}$, Sunarti Sunarti ${ }^{4}$, Rosmala Nur $^{5}$, Syaiful Hendra ${ }^{6}$ \\ ${ }^{1}$ Department of Biochemistry, Faculty of Medicine, Universitas Tadulako, Indonesia; ${ }^{2}$ Department of Health Nutrition, Faculty of \\ Medicine, Universitas Gadjah Mada, Indonesia; ${ }^{3}$ Department of Biochemistry, Poltekkes, Banjarmasin, Indonesia; ${ }^{4}$ Department \\ of Biochemistry, Faculty of Medicine, Universitas Gadjah Mada, Indonesia; ${ }^{5}$ Department of Public Health, Faculty of Public \\ Health, Tadulako University, Palu, Indonesia; ${ }^{6}$ Department of Information Technology, Faculty of Engineering, Tadulako \\ University, Palu, Indonesia
}

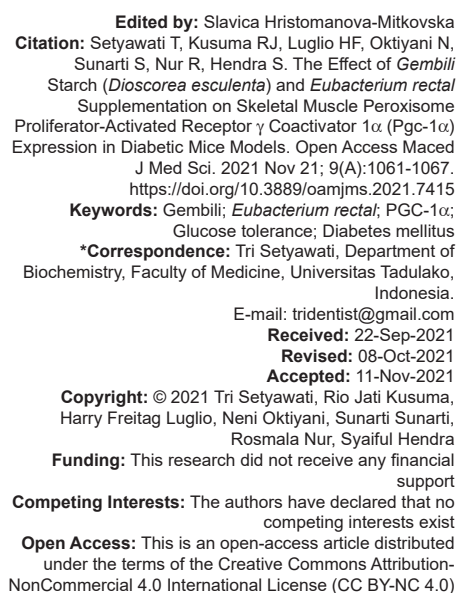

\begin{abstract}
BACKGROUND: Gembili or Dioscorea esculenta is a local food that is produced by several areas in Indonesia. Few studies have reported its health benefits for diabetes mellitus but a little is understood about its mechanism of action. PGC-1 $\alpha$ is a transcriptional coactivator for genes that involved in energy metabolism and increased expression of this gene has previously been associated with improved insulin sensitivity.

AIM: The objective of this study was to investigate the effect of Gembili starch and Gembili starch with butirogenic bacteria Eubacterium rectal on PGC-1 $\alpha$ expression in skeletal muscle of diabetic mice.

MATERIALS AND METHODS: Three months old male diabetic Wistar mice were divided into groups based on dietary supplement: Gembili starch only; Gembili starch with E. rectal; and E. rectal only. Positive (diabetic mice) and negative (non-diabetic) control groups were used in this study. After 4 weeks of supplementation, mice were sacrificed and muscle tissue was taken from musculus vastus latissimus. Plasma blood glucose was measured before and after intervention. PGC-1 $\alpha$ expression was measured with immunohistochemistry and quantified by dividing cells that produce PGC- $1 \alpha$ with total cells.

RESULTS: Plasma blood glucose was reduced after invention in group that received Gembili starch only $(p<0.001)$; Gembili starch with E. rectal $(p<0.001)$; and E. rectal only $(p<0.001)$. The protein expression of PGC-1 $\alpha$ in diabetic mice receiving Gembili starch only was significantly higher compared to control $(p<0.05)$.

CONCLUSION: This study shown that Gembili starch supplementation was able to improve glucose control in diabetic mice and this effect was obtained perhaps through PGC-1 $\alpha$ activation. Further study is needed to investigate the effect of Gembili starch supplementation on fat metabolism.
\end{abstract}

\section{Introduction}

Type 2 diabetes mellitus (T2DM) is a metabolic disorder of glucose homeostasis which associated insulin resistance and pancreatic ß-cell defects in stimulated insulin secretion. This condition induced the impaired glucose tolerance to occur [1]. The total number of people with diabetes is estimated to increase from $8.8 \%$ (approximately 415 million) in 2015 to $10.4 \%$ (approximately 642 million) in 2040 [2]. T2DM has become one of the major health problems in developing countries. T2DM accounts for more than $90 \%$ of people with diabetes [3], [4]. The disease is an example of pathological state when body cannot balance energy homeostasis and often clinically manifested as insulin resistance [5], [6]. Energy metabolism, especially in skeletal muscle, is finely controlled and the disturbance of regulation of this process frequently seen in diabetes and aging [7]. Studies have demonstrated that several gene expressions involved in lipid oxidation and mitochondrial metabolism were decreased in T2DM patients [8], [9].

Peroxisome proliferator-activated receptor gamma (PPAR- $\gamma$ ) coactivator-1- $\alpha$ (PGC-1 $\alpha$ ) plays an important role in the regulation of cellular energy metabolism [10]. PPAR- $\gamma$ coactivator-1- $\alpha$ (PGC-1 $\alpha$ ) has ability to promote and regulate expression of genes involved in lipid oxidation and mitochondrial metabolism [7], [11]. This protein is mainly expressed in tissues with high-energy oxidative capacity such as skeletal muscle, brown adipose tissue, and brain [7], [11]. Several in vitro studies had revealed that PGC- $1 \alpha$ is able to increase mitochondrial biogenesis and utilization of substrate for energy production [12], [13]. Interestingly, clinical studies discovered that patients with T2DM as well as insulin resistance had decreased skeletal 
muscle PGC-1 $\alpha$ expression [9], [10], [14] supporting the hypothesis that PGC- $1 \alpha$ is an important molecular signal that stands between T2DM and disturbance of energy metabolism.

Gembili or Dioscorea esculenta is a member of yams (Dioscorea spp.) family and widely grown in Indonesia. Studies have shown that this type of food commodity provides water-soluble polysaccharides (WSP) [15]. When carbohydrates were not well digested and the absorption of sugars in the small intestine was inhibited, the digesta was transferred into the colon and then fermented by bacteria producing short chain fatty acids (SCFAs) [16]. The previous studies have shown the hypoglycemic effect of $D$. esculenta in vivo [17], [18] but the mechanism of action is less understood. Therefore, the objective of this study was to investigate the effect $D$. esculenta and its combination with butyrogenic bacteria on molecular signal that involved in glucose homeostasis. Our hypothesis is that $D$. esculenta is able to modulate PGC- $1 \alpha$ thus ameliorate plasma glucose level in diabetic mice.

\section{Materials and Methods}

Thirty-eight male Wistar mice aged 3 months old were taken from Unit 4, LPPT (Lembaga Penelitian dan Pengembangan Terpadu/Institute for Research and Development) Universitas Gadjah Mada. Those mice were located at plastic cages with controlled temperature and $12 \mathrm{~h}$ light cycle. After 7 days of adaptation period, mice were grouped into five treatment groups which four of those groups were induced for diabetic using streptozotocin (60 mg/kg body weight). Those groups including: DM Con is a control group of diabetic mice; DM But is a group of diabetic mice receiving butirogenic bacteria Eubacterium rectal supplement only; DM Gs is a group of diabetic mice receiving Gembili starch supplement only; and DM Gs+But is a group of diabetic mice receiving butirogenic bacteria E. rectal and Gembili starch supplement. Every group is consisted by seven mice.

Every groups in this experiments received standard diet AIN-76 and treatments were given as a supplement to the diet. Gembili starch supplement was given orally by dissolving it into aquadest $(10 \% \mathrm{w} / \mathrm{v})$. The dosage of this supplement was $0.54 \mathrm{~g} /$ day based on human conversion ( $30 \mathrm{~g} /$ day for a human with $70 \mathrm{~kg}$ body weight). Freeze-dried butirogenic bacteria $E$. rectal (108 CFU/g) were dissolved into $1 \%$ concentration into aquadest and given orally. These treatments were done in 4 weeks.

Before and after intervention, fasting plasma glucose was measured. On the other hand, plasma insulin, glucose tolerance test, and PGC- $1 \alpha$ expression were measured only after intervention. Plasma glucose was measured by Diasys kit. Blood was taken through sinus orbitalis then centrifuge for 15-20 min with $3500 \mathrm{rpm}$. After separated from the blood, $10 \mu \mathrm{l}$ of plasma was taken to be mixed with $1 \mathrm{ml}$ GOD PAP glucose kit using vortex. Following step was incubation in $37^{\circ} \mathrm{C}$ for $10 \mathrm{~min}$ and the absorbance was measured using spectrophotometer in $500 \mathrm{~nm}$ wavelength. Insulin level was measured using ELISA. HOMA IR or homeostasis model assessment is indicator of insulin sensitivity and calculated using data of plasma glucose and insulin level. To analyze glucose tolerance, 0.75 unit/kg body weight of insulin was administered through intraperitoneal. Plasma glucose was measured before (0 min), $15 \mathrm{~min}$, and $30 \mathrm{~min}$ after insulin injection. Mice were fasting $4 \mathrm{~h}$ before insulin administration.

After being sacrificed, skeletal muscle tissue from musculus vastus latissimus was taken placed in $10 \%$ formalin solution. After $24 \mathrm{~h}$, the tissue was transferred into ethanol solutions from 50\% until $100 \%$ for dehydration at least 2 times. The following treatments were soaking the tissue inside xylol solution and insertion of liquid paraffin. After paraffin tissue obtained, the tissue then sliced into layers. Those layer then used for immunohistochemistry staining. Based on immunohistochemistry staining, total cells and cell expressed PGC-1 $\alpha$ were counted. The value of PGC-1 $\alpha$ expression was calculated by percentage of cell expressed PGC-1 $\alpha$ compared to total cells.

Statistical analysis was done using PRISM. One-way ANOVA was used to analyze differences of changes in fasting glucose plasma, HOMA IR, and expression of PGC-1 $\alpha$ in skeletal muscle between treatment groups. Student's t-test was used to compare significance of changes of fasting glucose plasma, HOMAIR, and expression of PGC- $1 \alpha$ between treatment groups (DM But, DM Gs, and DM Gs+But) compared to diabetic control mice (DM Con). Correlation analysis was done to measure whether expression of PGC-1 $\alpha$ was related to changes plasma glucose. The cutoff for statistical significance on these analyses was $p<0.05$.

\section{Results}

Initially, there are no differences on body weight between mice in different treatment groups (pANOVA $=0.670)$. After 4 weeks of treatments, mean body weight between treatment groups was significantly different (pANOVA $=0.004)$. Diabetic mice with Gembili starch and E. rectal butirogenic (DM Gs+But) and nondiabetic control (non-DM Con) mice were significantly increased body weight $(p=0.02$ and $p=0.008$, respectively). On the other hand, there are no changes in body weight on diabetic control group (DM Con, $p=0.880$ ), diabetic group receiving butirogenic bacteria $E$. rectal supplement only (DM But, $p=0.268$ ), and diabetic group receiving Gembili starch only (DM Gs, $p=0.09$ ). 


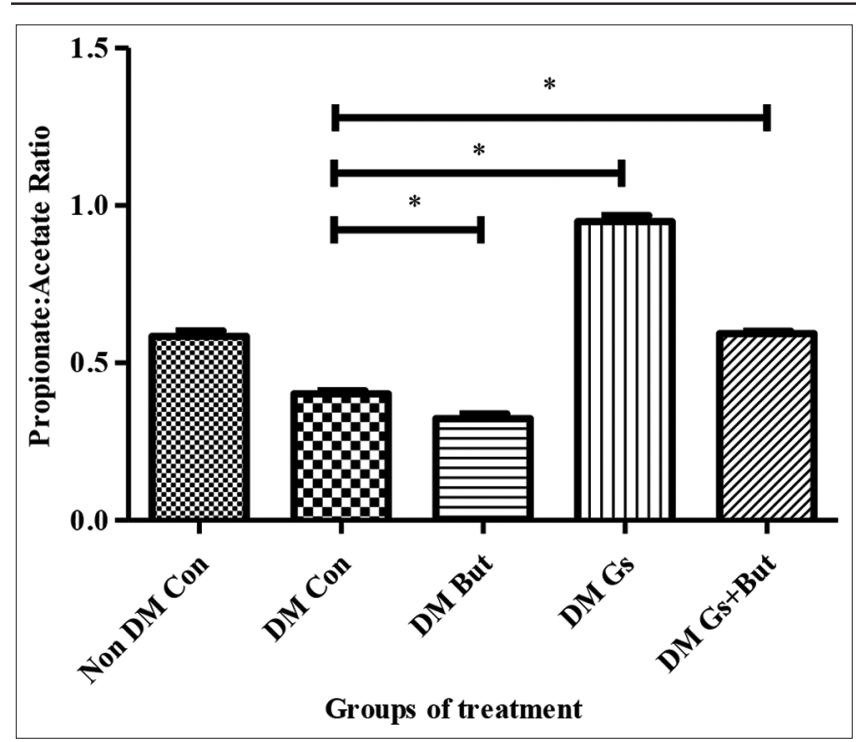

Figure 1: The effect of gembili starch and Eubacterium rectal treatments on propionate:acetate ratio. Treatments were done in non-diabetic control groups (Non DM Con, $n=5)$; diabetic control group (DM Con, $n=5$ ); diabetic group receiving butriogenic bacteria Eubacterium rectal supplement only (DM But, $n=7)$; diabetic group receiving gembili starch only (DM Gs, $n=7)$; and diabetic group receiving gembili starch combined with butriogenic bacteria Eubacterium rectal supplement (DM Gs+But, $n=7)$. Values in the graph was presented as mean \pm SEM. * $p<0.05$ (Student's $t$ test)

Plasma propionate:acetate ratio differed between treatment groups ( $p<0.0001)$ (Figure 1). Diabetic mice treated with Gembili starch supplement (DM Gs) and Gembili starch with E. rectal supplement (dm Gs+But) had higher propionate:acetate ratio compared to control ( $p<0.0001$ for all). Figure 2 shows the effect of combination treatments of Gembili starch and $E$. rectal on HOMAIR and changes of plasma glucose level. HOMA IR value was calculated using data on plasma glucose and insulin. As presented in Figure 2a, diabetic mice in DM But, DM Gs, and DM Gs+But groups had significantly lower HOMA IR compared to control (DM Con) (all $p<0.0001)$. The changes of plasma glucose level were obtained by reducing fasting plasma glucose level 4 weeks after treatments with baseline (Figure 2b). Compared to control, changes of plasma glucose was significantly lower in DM But (mean difference \pm SEM: $109.20 \pm 28.46 \mathrm{mg} / \mathrm{dL}$, $\mathrm{p}=0.003$ ); DM Gs (mean difference \pm SEM: $61.68 \pm 19.86 \mathrm{mg} / \mathrm{dL}, \mathrm{p}=0.01$ ); and DM Gs+But (mean difference \pm SEM: $109.8 \pm 27.67 \mathrm{mg} / \mathrm{dL}, \mathrm{p}=0.003$ ).

Glucose tolerance test was done by measuring the plasma glucose concentration 15 and 30 minutes after intraperitoneal insulin administration (Figure 3). The changes of plasma glucose were calculated by comparing percent reduction of plasma glucose with baseline. After $15 \mathrm{~min}$, DM But and DM Gs+But reduced more glucose compared to DM Con $(p=0.002$ and $p<0.0001$, respectively) while DM Gs reduced less glucose compared to DM Con ( $p=0.0016)$. After 30 min, DM But and DM Gs+But also reduced more glucose compared to DM Con ( $p=0.002$ and $p=0.0004$, respectively) while there are no differences between DM Gs and DM Con.

The expression of PGC-1 $1 \alpha$ of skeletal muscle cells is shown in Figure 4. Compared to non-DM Con, DM Con had lower expression

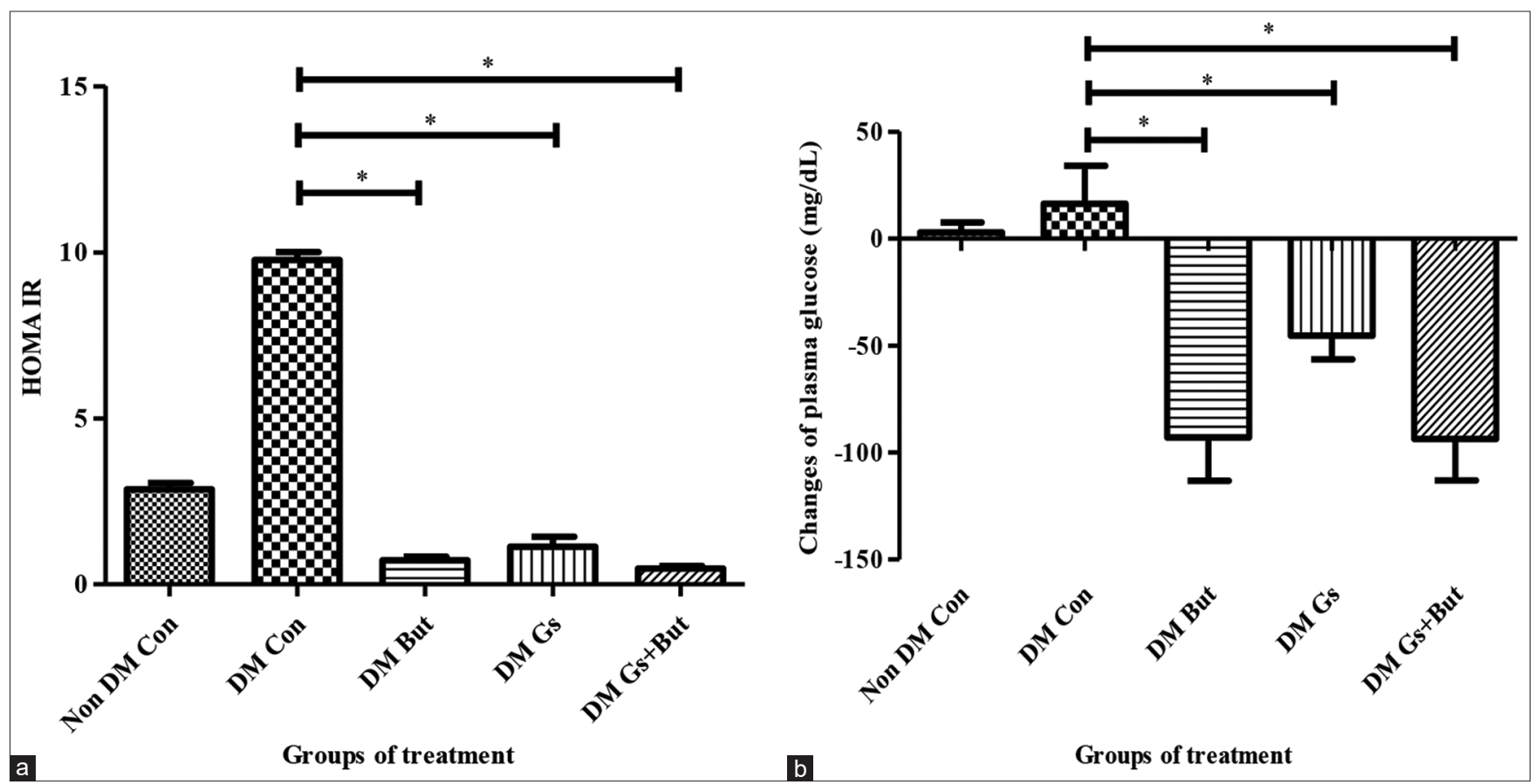

Figure 2: The effect of gembili starch and Eubacterium rectal treatments on HOMA IR (a) and changes of fasting plasma glucose level (b). Treatments were done in non-diabetic control groups (Non DM Con, $n=5)$; diabetic control group (DM Con, $n=5)$; diabetic group receiving butriogenic bacteria Eubacterium rectal supplement only (DM But, $n=7)$; diabetic group receiving gembili starch only (DM Gs, $n=7)$; and diabetic group receiving gembili starch combined with butriogenic bacteria Eubacterium rectal supplement (DM Gs+But, $n=7)$. Values in the graph was presented as mean \pm SEM. * $p<0.05$ (Student's $t$ test) 


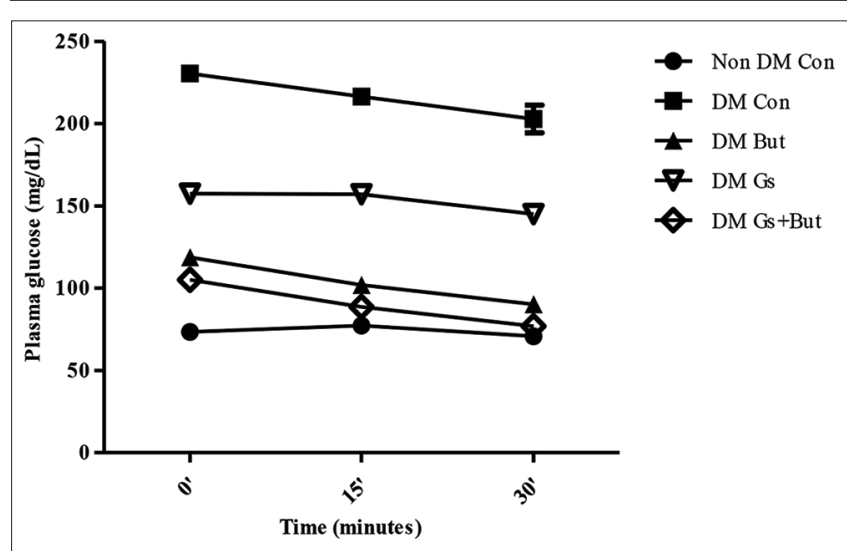

Figure 3: Glucose tolerance test after treatments in non-diabetic control groups (Non DM Con, $n=5$ ); diabetic control group (DM Con, $n=5)$; diabetic group receiving butriogenic bacteria supplement only (DM But, $n=6)$; diabetic group receiving gembili starch only (DM Gs, $n=6)$; and diabetic group receiving gembili starch combined with butriogenic bacteria supplement (DM Gs+But, $n=6)$. Values in the graph were presented as mean \pm SEM

(mean difference: $13.36 \pm 4.559, p=0.019$ ) of skeletal muscle PGC-1 $\alpha$ expression. After 4 weeks of treatments, DM But and DM Gs+But had higher skeletal muscle PGC- $1 \alpha$ compared to control diabetic mice (mean differences: $-22.93 \pm 3.830, p=0.001$ and mean differences: $-12.77 \pm 5.218, p=0.03$, respectively). The difference has not seen in DM Gs group. To evaluate whether skeletal muscle, PGC- $1 \alpha$ expression is related to changes in fasting plasma glucose, a correlation

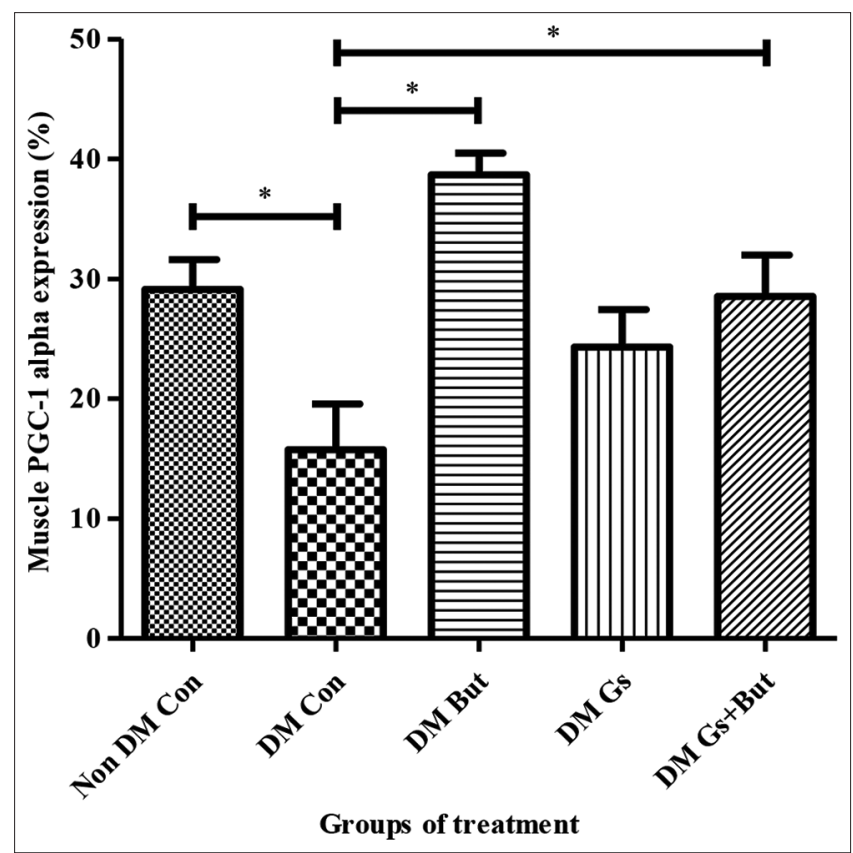

Figure 4: PGC-1 a expression level after treatments in non-diabetic control groups (Non DM Con, $n=5)$; diabetic control group (DM Con, $n=5)$; diabetic group receiving butriogenic bacteria supplement only (DM But, $n=6$ ); diabetic group receiving gembili starch only (DM Gs, $n=6)$; and diabetic group receiving gembili starch combined with butriogenic bacteria supplement (DM Gs+But, $n=6)$. Values in the graph was presented as mean \pm SEM. * shows significant differences between groups of diabetic mice receiving treatments and control diabetic mice analysis was done in all dataset regarding groups of treatment. Figure 5 shows that PGC- $1 \alpha$ expression was negatively correlated with changes of plasma glucose after 4 weeks of treatments $\left(r^{2}=0.163, p=0.02\right)$.

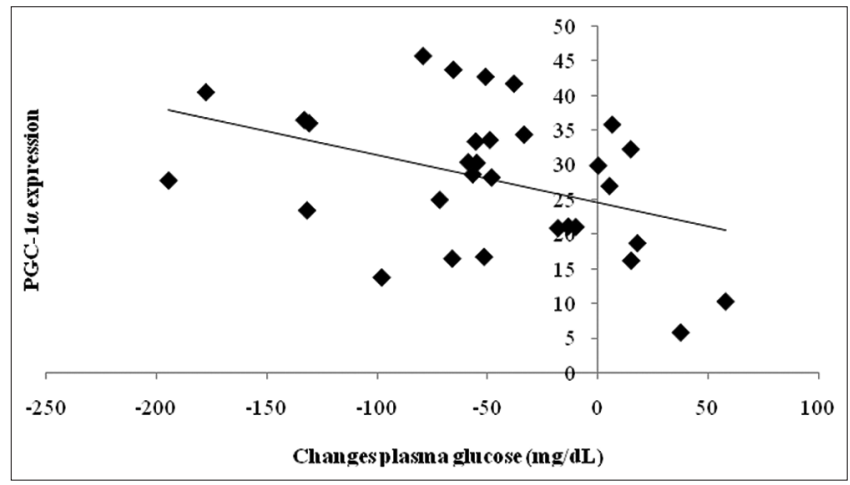

Figure 5: Relationship between changes of plasma glucose level and skeletal muscle PGC-1a expression after treatments in all used data

\section{Discussion}

PPAR- $\gamma$ coactivator-1- $\alpha \quad(\mathrm{PGC}-1 \alpha)$ is a coactivator that increases the transcriptional activity of multiple pathways. The role of PGC-1a in control of inflammation, mitochondrial respiration and biogenesis are very important. The expression of more than $70 \%$ of all the subunits of the electron transport chain and all of the enzymes of the Krebs cycle are controlled by PGC- $1 \alpha$ in the heart. At present, PGC-1 $\alpha$-mediated mitochondrial protein synthesis and anti-inflammatory benefits are reported to be dependent on insulin sensitivity or glycemic improvements in skeletal muscle or adipose tissues [9].

This study shown that skeletal muscle PGC-1 $\alpha$ expression was higher in diabetic mice consuming Gembili starch combined with E. rectal supplements compared to control diabetic mice. In diabetic mice consuming the supplement of butirogenic $E$. rectal with Gembili starch, fasting plasma glucose was reduced significantly and this reduction was related with the increment of PGC-1 $\alpha$ expression in skeletal muscle. To the best of our knowledge, this is the first study that analyzes the effect of Gembili starch and its combination with butirogenic bacteria $E$. rectal supplements on PGC-1 $\alpha$ expression in skeletal muscle.

Until recently, there is a lack of evidence on the effect of WSP on PGC- $1 \alpha$ expression. However, we proposed that the effect of Gembili starch supplement on PGC- $1 \alpha$ expression is through 5-AMP-activated protein kinase (AMPK) activation by SCFA produced fermentation of WSP contained Gembili starch. WSP escaped enzymatic digestion in the small intestine and fermented in large intestine by colonic bacteria. The fermentation of WSP increases production of SCFA including acetate, propionate, and butyrate [19]. 
Because butyrate is directly used by mucosal colon, changes of propionate and acetate plasma ratio due to fermentation can explain biological effect of Gembili starch. In line with this study, we found that propionate:acetate ratio was higher in diabetic mice received Gembili starch and Gembili starch with E. rectal supplements compared to control. There are a limited number of information regarding the effect of SCFA and AMPK activation. In diabetic mice, 8 weeks acetic acid was able to activate hepatic AMPK. This finding is followed by the additional data which shown that fasting plasma glucose and $\mathrm{HbA} 1 \mathrm{c}$ were lower in acetic acid treatment compared to control [20]. Unfortunately, in this study, AMPK has not been analyzed to clarify this evidence.

The fermentation of dietary fiber to various organic acids in colon has a beneficial function. In particular, butyric acid contributes to host health by facilitating maintenance of epithelial integrity, regulating inflammation, and influencing gene expression in colonocytes [21]. The microbiota in the large intestine provides several functions that are beneficial to human health such as producing short-chain fatty acids. The short fatty acid products can improve these beneficial functions could promote health and reduce the incidence of preventable diseases including obesity and type 2 diabetes [22] or colon cancer [23].

Like in Figure 3, it showed that DM group receiving gembili starch combined with butriogenic bacteria supplement (DM Gs+But, n=6). But and DM Gs+But reduced more glucose compared to DM Control $(p=0.002$ and $p<0.0001$ respectively). Moreover, while DM with Gembili starch (Gs) reduced less glucose compared to DM Con ( $p=0.0016)$. After 30 min, DM But and DM Gs+But also reduced more glucose compared to $D M$ control $(p=0.002$ and $p=0.0004$, respectively. This proves that the administration of resistant starch from Gembili starch and also E. rectal supplements can prevent an increase in plasma glucose levels [22]. The ability of strains of $E$. rectal shows in this research. Strains of $E$. rectal are able to degrade and utilize a variety of carbohydrates for growth which were tested by anaerobic culturing [24]. Nine of the 10 strains were able to utilize amylopectin and/or amylose for growth interactions between microbial cells and cell components, the short-chain fatty acid products of carbohydrate fermentation as Gembili starch by gut bacteria exert multiple effects on the host as energy sources, and as regulators of inflammation, proliferation, and apoptosis [25].

It has been reviewed before that PGC- $1 \alpha$ has an important role on the regulation of energy metabolism [22], [26]. This function includes controlling adipose tissue thermogenesis, fiber-type switching on muscle cells, fasting response on the liver, and insulin sensitivity [6], [20]. In this study, we were able to show that PGC- $1 \alpha$ is decreased in diabetic mice compared to non-diabetic mice. In addition, mice treated with
Gembili starch combined with E. rectal supplements had higher PGC-1 $\alpha$ as well as lower fasting plasma glucose compared to diabetic control. These findings are supported by a clinical trial in human. Mensink et al. [26] demonstrated that skeletal muscle PGC-1 $\alpha$ expression was increased obese patients with T2DM after treated with rosiglitazone.

Although no studies had reported the effect of Gembili starch combined with E. rectal on muscle PGC-1 $1 \alpha$ expression and fasting plasma glucose before, few studies done in Indonesia have indicated that Gembili starch was able to reduce fasting plasma in diabetic mice. Harijono et al. [17] shown that 4 weeks supplementation of WSP extracted from Gembili alone or with combination with papain or tempeh inoculum was able to reduce fasting blood glucose. The hypoglycemic effect of Gembili in the food product like biscuit was still seen in diabetic mice after 4 weeks of treatment [14]

Gembili starch with E. rectal showed the effect on increasing of PGC-1 $\alpha$ expression. In addition, several studies have also found that the glucocorticoid (GC) group which is generally given as an antiinflammatory can also increase the expression of PGC-1 $\alpha$. GCs, such as dexamethasone, prednisone, and hydrocortisone, are often prescribed as antiinflammatory agents [27]. Recently, they have been gradually recognized as the important regulators of diabetes mellitus because of their critical roles in peripheral IR and $\beta$-cell insulin secretion. In the liver, the function of GCs is ultimately complex and partly mediated by PGC-1 $\alpha$ [28].

In addition, classes of drugs such as salbutamol also have effects on PGC-1 $1 \alpha$ expression. Salbutamol beneficial effect persisted after 4 weeks of its discontinuation. HFD caused an upregulation of the hepatic PGC-1 $\alpha$ expression by 5.23 -fold ( $p<0.041$ ) and salbutamol reversed this effect and caused a downregulation by 30.3 -fold ( $p<0.0001$ ). PGC-1 $\alpha$ and GLUT4 expression in the muscle were not affected by salbutamol $(p>0.05)$ [29].

Besides Gembili flour or a combination of E. rectal, the important thing to do is through exercise in aerobe condition. According to Botta et al. (2013), that short-term exercise-induced oxidative stress may be key in attenuating cardiac inflammatory genes and impairing PGC-1 $\alpha$-mediated gene transcription of downstream transcription factors in type 2 diabetic hearts at an advanced age [30]. However, such an exercise regimen was able to increase both mRNA and protein levels of cardiac PGC- $1 \alpha$ in $\mathrm{db} / \mathrm{db}$ mice hearts [31].

Due to limited funding, immunohistochemistry was used as a parameter for PGC- $1 \alpha$ expression instead of RT-PCR. Authors realized that this could have negative impact on generalizing the data. However, this study was attempted to be the first data that could 
be collected. Several tissues have been stored and proposed to further investigate for gene expression related to insulin signaling.

\section{Conclusion}

We conclude that supplementation of Gembili starch in combination with $E$. rectal was able to improve fasting plasma glucose level in diabetic mice through amelioration of PGC- $1 \alpha$. This study has an important implication on developing local based food as an option for nutrition treatment for T2DM patients. This funding also provides basic evidence on the effect of function food on molecular level thus future study that bring this finding into clinical trial is warranted.

\section{References}

1. Soumaya K. Molecular mechanisms of insulin resistance in diabetes. Adv Exp Med Biol. 2012;771:240-51. http://doi. org/10.1007/978-1-4614-5441-0_19 PMid:23393683

2. International Diabetes Federation. IDF Diabetes Atlas. $7^{\text {th }}$ ed. International Diabetes Federation; 2015.

3. Zheng Y, Ley SH, Hu FB. Global aetiology and epidemiology of Type 2 diabetes mellitus and its complications. Nat Rev Endocrinol. 2018;14(2):88-98. http://doi.org/10.1038/ nrendo.2017.151

PMid:29219149

4. Chatterjee S, Khunti K, Davies MJ. Type 2 diabetes. Lancet. 2017;389(10085):2239-51. http://doi.org/10.1016/ S0140-6736(17)30058-2

PMid:28190580

5. DeFronzo RA, Simonson D, Ferrannini E. Hepatic and peripheral insulin resistance: A common feature of Type 2 (noninsulin-dependent) and Type 1 (insuin-dependent) diabetes mellitus. Diabetologia. 1982;23(4):313-9. http://doi.org/10.1007/ BF00253736

PMid:6754515

6. Canto C, Auwerx J. PGC-1 alpha SIRT1 and AMPK, an energy sensing network that controls energy expenditure. Curr Opin Lipidol. 2009;20:98-105. http://doi.org/10.1097/ MOL.0b013e328328d0a4 PMid: 19276888

7. Attie $A D$, Kendziorski CM. PGC-1 alpha at the crossroads of Type 2 diabetes. Nat Genet. 2003;34(3):244-5. http://doi. org/10.1038/ng0703-244

PMid:12833045

8. Patti ME, Butte AJ, Crunkhorn S, Cusi K, Berria R, Kashyap $\mathrm{S}$, et al. Coordinated reduction of genes of oxidatve metabolism in humans with insulin resistance and diabetes: Potential role of PGC1 and NRF1. Proc Natl Acad Sci U S A. 2003;100(14):8466-71. http://doi.org/10.1073/ pnas. 1032913100

PMid:12832613
9. Mootha VK, Lindgren CM, Eriksson KF, Subramanian A, Sihag S, Lehar J, et al. PGC-1 alpha-responsive genes involved in oxidative phosphorilation are coordinately downregulated in human diabetes. Nat Genet. 2003;34(3):267-73. http://doi. org/10.1038/ng1180

PMid: 12808457

10. Wende A, Schaeffer PJ, Parker GJ, Zechner C, Han DH, Chen MM, et al. A role for the transcriptional coactivator PGC-1 alpha in muscle refueling. J Biolchem. 2007;282(50):36642-51. http://doi.org/10.1074/jbc.M707006200

PMid:17932032

11. Mootha VK, Handschin C, Arlow D, Xie X, St Pierre J, Sihag S, et al. Erralpha and Gabpa/b speciify PGC-1 alpha-dependent oxidative phosphorilation gene expression that is altered in diabetic muscle. Proc Natl Acad Sci U S A. 2004;101:6570-5. http://doi.org/10.1073/pnas.0401401101

PMid: 15100410

12. Wu Z, Puigserver P, Andersson U, Zhang C, Adelmant G Mootha V, Troy A, et al. Mechanism controlling mitochondrial biogenesis and respiration through the thermogenic coactivator PGC-1. Cell. 1999;98(1):115-24. http://doi.org/10.1016/ S0092-8674(00)80611-X

PMid:10412986

13. St-Pierre J, Lin J, Krauss S, Tarr PT, Yang R, Newgard CB Spiegelman BM. Bioenergetic analysis of peroxisome proliferator-activated receptor gamma coactivator-1- alpha and 1beta (PGC-1alpha and PGC 1beta) in muscle cells. J Biol Chem. 2003;278(29):26597-603. http://doi.org/10.1074/jbc. M301850200

PMid: 12734177

14. Richardson DK, Kashyap S, Bajaj M, Cusi K, Mandarino SJ, Finlayson $\mathrm{J}$, et al. Lipid infusion decreases the expression of nuclear encoded mithocondrial genes and increases the expression od extracellular matrix genes in human skeletal muscle. J Biol Chem. 2005;280(11):10290-7. http://doi. org/10.1074/jbc.M408985200

PMid:15598661

15. Liu YW, Shang HF, Wang CK, Hsu FL, Hou WC. Immunomodulatory activity of dioscorin, the storage protein of yam (Dioscorea alata cv. Tainong no.1) tuber. Food Chem Toxicol. 2007;45(11):2312-8. 10.1016/j.fct.2007.06.009 PMid: 17637490

16. Lunn J, Buttriss JL. Carbohydrates and dietary fbre. Nutr Bull. 2007;32:21-64

17. Harijono, Estiasih T, Sunarharum WB, Hartono MD. Hypoglycemic effect of biscuits containing water-soluble polysaccharides from wild yam (Dioscorea hispida Dennts) or lesser yam (Dioscorea esculenta) tubers and alginate. Int Food Res J. 2013;20(5):2279-85.

18. Estiasih HT, Sunarharum WB, Suwita IK. Efek hipoglikemik polisakarida larut air gembili (Dioscorea esculenta) extracted by various methods. Indo Food Technol J. 2012;23(1):1-8.

19. Theuwissen E, Mensink RP. Water-soluble dietary fibers and cardiovascular disease. Physiol Behav. 2008;94(2):285-92. http://doi.org/10.1016/j.physbeh.2008.01.001 PMid:18302966

20. Sakakibara S, Yamauchi T, Oshima Y, Tsukamoto Y, Kadowaki T. Acetic acid activates hepatic AMPK and reduces hyperglycemia in diabetic KK-A(y) mice. Biochem Biophys Res Commun. 2006;344(2):597-604. http://doi.org/10.1016/j.bbrc.2006.03.176 PMid: 16630552

21. Flint HJ, Duncan SH, Scott KP, Louis P. Links between diet, gut microbiota composition and gut metabolism. Proc Nutr Soc. 2015;74(1):13-22.

PMid:25268552 
22. Hartstra AV, Bouter KE, Backhed F, Nieuwdorp M. Insights into the role of the microbiome in obesity and Type 2 diabetes. Diabetes Care. 2015;38(1):159-65. http://doi.org/10.2337/ dc14-0769

PMid:25538312

23. Zackular JP, Baxter NT, Iverson KD, Sadler WD, Petrosino JF, Chen GY, et al. The gut microbiome modulates colon tumorigenesis. mBio. 2013;4(6):e00692. http://doi.org/10.1128/ mBio.00692-13

PMid:24194538

24. Sheridan PO, Martin JC, Lawley TD, Hillary PB, Harris HM, Bernalier-Donadille $\mathrm{A}$, et al. Polysaccharide utilization loci and nutritional specialization in a dominant group of butyrate-producing human colonic firmicutes. Microb Genom. 2016;2(2):e000043. http://doi.org/10.1099/mgen.0.000043 PMid:28348841

25. Louis P, Hold GL, Flint HJ. The gut microbiota, bacterial metabolites and colorectal cancer. Nat Rev Microbiol. 2014;12(10):661-72. http://doi.org/10.1038/nrmicro3344 PMid:25198138

26. Mensink M, Hesselink MK, Russell AP, Schaart G, Sels JP Schrauwen P. Improved skeletal muscle oxidative enzyme activity and restoration of PGC-1 alpha and PPAR beta/ delta gene expression upon rosiglizatone treatment in obese patients with Type 2 diabetes mellitus. Int $\mathrm{J}$ Obes (Lond). 2007;31(8):1302-10. http://doi.org/10.1038/sj.ijo.0803567

\section{PMid: 17310221}

27. Puigserver $P$. Tissue-specific regulation of metabolic pathways through the transcriptional coactivator PGC- $1 \alpha$. Int J Obes. 2005;29(Suppl 1):S5-9. http://doi.org/10.1038/ sj.ijo.0802905

PMid:15711583

28. Herzig S, Long F, Jhala US, Hedrick S, Quinn R, Bauer A et al. CREB regulates hepatic gluconeogenesis through the coactivator PGC-1. Nature. 2001;413(6852):3179-183. http:// doi.org/10.1038/35093131

PMid:11557984

29. Saleh N, Elayan HE, Zihlif M. The effect of salbutamol on PGC-1o and GLUT4 mRNA expression in the liver and muscle of elderly diabetic mice. Acta Endocrinol (Buchar). 2018;14(2):184-91. http://doi.org/10.4183/aeb.2018.184

PMid:31149256

30. Botta A, Laher I, Beam J, Decoffe D, Brown K, Halder S, et al Short term exercise induces PGC-1 $\alpha$, ameliorates inflamation and increases mitochondrial membrane proteins but fail to increase respiratory enzymes in aging diabetic hearts. PLoS One. 2013;8(8):e70248.

PMid:23936397

31. Handschin C, Spiegelman BM. The role of exercise and PGC-1 alpha in inflammation and chronic disease. Nature. 2008;454(7203):463-9. http://doi.org/10.1038/nature07206 PMid:18650917 